Article

\title{
Biochar and Vermicompost Amendments Affect Substrate Properties and Plant Growth of Basil and Tomato
}

\author{
Lan Huang ${ }^{1}{ }^{(}$, Mengmeng Gu ${ }^{2} \mathbb{D}$, Ping Yu ${ }^{3}$, Chunling Zhou ${ }^{4}$ and Xiuli Liu ${ }^{5, *}$ \\ 1 Institute of Urban Agriculture, Chinese Academy of Agricultural Sciences, Chengdu 610000, China; \\ huanglan_92@163.com \\ 2 Department of Horticultural Sciences, Texas A\&M AgriLife Extension Service, College Station, TX 77843, \\ USA; mgu@tamu.edu \\ 3 Department of Horticultural Sciences, Texas A\&M University, College Station, TX 77843, USA; \\ yuping520@tamu.edu \\ 4 School of Landscape Architecture \& Forestry, Qingdao Agricultural University, Qingdao 266109, China; \\ zhou_chl@sina.com \\ 5 School of Landscape Architecture, Beijing Forestry University, Beijing 100083, China \\ * Correspondence: showlyliu@bjfu.edu.cn; Tel.: +86-136-1104-0888
}

Received: 12 December 2019; Accepted: 1 February 2020; Published: 4 February 2020

\begin{abstract}
The suitability of biochar (BC) as a container substrate depends on the $\mathrm{BC}$ mix ratio and plant species. Mixes with mixed hardwood BC $(20 \%, 40 \%, 60 \%$, and $80 \%$, by volume $)$ and vermicompost (VC; $5 \%, 10 \%, 15 \%$, and $20 \%$, by volume) were evaluated as container substrates on basil (Ocimum basilicum L.) and tomato (Solanum lycopersicum L. 'Roma') plants compared to a commercial peat-based substrate (CS). The CS made up the rest of the volume when BC and VC did not add up to $100 \%$. The total porosity of all mixes with BC, VC, and CS (BC:VC:CS mixes) was similar to the control. Mixes with $80 \% \mathrm{BC}$ had lower container capacity than the control. At 9 weeks after transplanting, the leachate $\mathrm{pH}$ of all the $\mathrm{BC}: \mathrm{VC}: \mathrm{CS}$ mixes was higher than that of the control, except for mixes of $20 \% \mathrm{BC}$ and $5 \% \mathrm{VC}$ with the rest $(75 \%)$ being CS (20BC:5VC:75CS) and 20BC:10VC:70CS with tomato plants. The soil plant analysis development (SPAD) readings in BC:VC:CS mixes were similar to or higher than the control except for tomato plants in 80BC:5VC:15CS, 80BC:15VC:5CS, and 80BC:20VC:0CS mixes. Plants in BC:VC:CS mixes had similar growth indexes and total dry weight with respect to those in 100\% CS, with the root DW of basil plants in 60BC:15VC:25CS being the highest among all treatments. Therefore, the BC $(20 \%, 40 \%, 60 \%$, or $80 \%$, by volume) and VC $(5 \%, 10 \%, 15 \%$, or $20 \%$, by volume) mixes had the potential to replace CS for container-grown plants, with the estimate wholesale price for 80BC:5VC:15CS was only $61.6 \%$ that of the control.
\end{abstract}

Keywords: container; growing media; nursery production; carbon; peat moss; bioenergy

\section{Introduction}

Biochar (BC), attracting increasing interests in recent years for its use in agriculture, can be used to replace some components of commonly used container substrates [1-3]. Biochar could be made from the pyrolysis $[4,5]$ or gasification [6,7] of biomass. The main purpose of the bioenergy production process, pyrolysis and gasification, is to produce syngas or bio-oil $[4,8,9]$, and $\mathrm{BC}$ is the by-product. The application of $\mathrm{BC}$ in other fields including agriculture provides extra benefits to the bioenergy producers. Biochars can be made from green waste [10,11], wheat straw [12,13], wood [13,14], and rice hull [15], and are renewable and quickly generated [16]. Biochars produced from various raw materials or production conditions would be different and thus cause diverse effects when being incorporated in 
container substrates $[17,18]$. Meanwhile, BCs made from the same feedstock but with different fraction sizes could have different $\mathrm{pH}$ and nutrient levels [19].

The incorporation of $\mathrm{BC}$ in container substrates has many benefits. Ecological issues caused by extracting the most commonly used horticultural substrate constituent peat from peatlands has increased the necessity of using alternative growing media components including $\mathrm{BC}$ in the near future [20]. Research has shown that peatlands have been drained for peat use in agriculture for a long time, which led to the loss of carbon to the atmosphere [21]. Drained peatlands would cause the release of $1.91 \mathrm{Gt} \mathrm{CO}_{2}$-eq. contemporary annual greenhouse gas emission, and peatland rehabilitation is strongly needed [22]. Due to the environmental concern of using peat, the use of BC in containers substituting peat could be a more sustainable choice for the horticultural industry. Biochar in container substrates could increase water-holding capacity [23] and reduce nutrient leaching [24]. Furthermore, the incorporation of $\mathrm{BC}$ in peat-based substrate could increase substrate electrical conductivity (EC) and mineral nutrients uptake [25]. Many of the BCs used were alkaline and thus could be used to raise the $\mathrm{pH}$ of acidic substrate $[10,26,27]$.

Although BC in container substrates has a lot of benefits, different plant species and BC mix ratios in the container may lead to different results. Kadota and Niimi [28] concluded that mixing $10 \%$ or $30 \%$ (by volume) BC to the basal medium (substrate with peat, vermiculite, soil, and sand at the ratio of 2:1:1:1, by volume) caused enhanced zinnia (Zinnia linearis Benth) shoot growth but no positive effects on marigold (Tagetes patula L.) or scarlet sage (Salvia splendens Ker Gawl.). Mixes with potato anaerobic digestate and acidified wood pellet BC (1:1, by volume) increased tomato (Solanum lycopersicum L.) dry weight (DW) but decreased marigold DW compared to those in the 1:1 peat:vermiculite control [29]. Mixes of $50 \%$ or $70 \%$ (by volume) sugarcane bagasse $B C$ with the rest being bark-based container substrates led to decreased tomato total DW but no negative effects on basil DW compared to the control [30]. In addition to plant species, different percentages of BC mixed with other substrates components also led to diverse results. Gu et al. [31] has shown that the $\mathrm{BC}$ rate in pine bark mixes was positively correlated with gomphrena (Gomphrena globosa L.) fresh weight (FW) and DW. Housley et al. [32] found that the pansy (Viola hybrida Schur) aboveground DW was increased in the mixes with pine bark, coir, clinker ash, and coarse sand when incorporated with $2.5 \%(w / w)$ Sydney blue gum (Eucalyptus saligna Sm.) wood chip BC, while suppressed when incorporated with $10 \%(w / w)$ $\mathrm{BC}$, compared to the control. Webber et al. [33] also showed that the amendment of 50\% (by volume) pneumatic bagasse BC could increase squash (Cucurbita pepo L.) plant DW, but the amendment of $25 \%$ (by volume) BC caused no negative effect on plant DW in comparison with the control.

Vermicompost (VC) is produced by using worms to digest and thus break down organic matter, such as sewage sludge [34], animal waste [35-37], and crop residues [38]. Vermicompost is finely textured and rich in nutrients $[39,40]$, and it has good water-holding capacity [41]. Beneficial effects have been shown in a lot of studies in which VC was used in containers with other substrates. Atiyeh et al. [40] concluded that VC addition in container substrates would enhance plant growth. The swamp rose mallow (Hibiscus moscheutos L.) grown in containers with VC showed improved plant DW [42]. Vermicompost mixed with coir at a ratio of 2:1 $(w / w)$ as container substrate increased Swiss chard (Beta vulgaris L.) plant height and FW [43]. The substitution of peat-based growing media with VC $(10 \%, 20 \%, 30 \%, 40 \%$, and $50 \%$, by volume) and BC ( $4 \%, 8 \%$, and $12 \%$, by volume) did not cause any negative effect on the shoot DW of petunia (Petunia hybrida E.Vilm.) and pelargonium (Pelargonium peltatum L.) except pelargonium in mixes of $4 \%$ BC and $50 \%$ VC [44]. It was also shown that the plant size, flower production, and root growth capacity of petunia and pelargonium in $\mathrm{BC}$ $(4 \%, 8 \%$, and $12 \%$, by volume) and VC $(10 \%, 20 \%$, and $30 \%$, by volume) mixes was similar to or higher than those in the peat-based substrate control [45]. However, VC made from different parent materials could have different properties [46]. The addition of VC in container substrate may not always cause positive effects on plant growth. Liu et al. [47] have shown that the DW of vegetative and flower organs and growth index of pepper (Capsicum annuum L.) in BC (70\%, 80\%, and 90\%, by volume) mixes with VC were lower than those in the Sunshine \#1 Mix, which is a peat moss-based substrate. Therefore, 
although a specific percentage of certain VCs could be used as container substrates to grow plants, caution is also needed due to the complexity of VC.

Tomato (Solanum lycopersicum L.) and basil (Ocimum basilicum L.) are two widely consumed plants in the horticultural industry. Tomato is an important source of various antioxidant vitamins including ascorbic acid, tocopherols, vitamin C, and carotenoids [48]. Tomato plants are considered as "heavy feeder", requiring medium to high fertility [49]. Basil is referred to as the "king of the herbs" [50]. The essential oil of basil is used in various food products, perfumes, insecticides, medicines, and industrial products [51,52]. Basil is sensitive to high fertility [53]. It was shown that high fertility (500 $\mathrm{mg} \mathrm{N} \mathrm{L}^{-1}$ ) reduced the basil leaf area, when compared to the ones growing with $100 \mathrm{mg} \mathrm{N} \mathrm{L}^{-1}$ [54].

Few research studies have investigated combinations of BC with VC as container substrates. Due to the high cost of $\mathrm{VC}$ and the proneness to use more $\mathrm{BC}$ in containers to replace the commonly used peat-based substrate, low percentages of VC $(5 \%, 10 \%, 15 \%$, and $20 \%$, by volume) and wide range of percentages of $\mathrm{BC}(20 \%, 40 \%, 60 \%$, and $80 \%$, by volume) were used in this experiment. The purpose of this experiment was to test the potential of the mixed hardwood BC and VC mixes as replacements for a commercial peat-based substrate (CS). The specific objectives were to (1) investigate the physical and chemical properties of the BC and VC mixes; and (2) compare the impacts of different mixes of $\mathrm{BC}$ with VC on container-grown basil and tomato plants to $100 \%$ CS.

\section{Materials and Methods}

\subsection{Plant Materials and Container Substrates Treatments}

Tomato 'Roma' (Morgan County Seeds, Barnett, MO, USA) and basil seeds (Johnny's Selected Seeds, Winslow, ME, USA) were sown in commercial propagation mix (Propagation mix; Sun Gro ${ }^{\circledR}$ Horticulture, Agawam, MA, USA) in plug trays on 28 October 2016. One tomato seed and four basil seeds were sown per cell (hexagon with side length of $2.6 \mathrm{~cm}$; height: $4.2 \mathrm{~cm}$; volume: $20 \mathrm{~mL}$ ). Uniform basil and tomato seedlings were selected and transplanted into the experimental substrates in pots (depth: $10.8 \mathrm{~cm}$; top diameter: $15.5 \mathrm{~cm}$; bottom diameter: $11.3 \mathrm{~cm}$; volume: $1330 \mathrm{~mL}$ ) on 16 November 2016 after true leaves emerged. Each container contained one tomato seedling or four basil seedlings. Sixteen BC and VC mixes were formulated by mixing four rates of BC $(20 \%, 40 \%, 60 \%$, and $80 \%$, by volume; a by-product of fast pyrolysis of mixed hardwood, Proton Power, Inc., Lenior City, TN, USA) with four rates of VC $(5 \%, 10 \%, 15 \%$, and $20 \%$, by volume; Pachamama earthworm castings; Lady Bug Brand, Conroe, TX, USA). The CS (BM7 35BKS; Berger, Saint-Modeste, QC, Canada) made up the rest of the volume when the BC and VC did not add up to $100 \%$. The CS was used as the control (Figure 1). The CS (Berger BM7 35BKS) used in this research consisted of 55\% coarse peat moss, $35 \%$ pine bark, and 10\% horticultural perlite. The wholesale price for the mixed hardwood $\mathrm{BC}$ was $\$ 65.4$ per cubic meter (Personal Communication). The wholesale price was approximately $\$ 176.6$ per cubic meter for the CS (Berger BM7 35BKS) and \$607.4 per cubic meter for the VC [55]. The estimated wholesale price for the 17 different substrates per cubic meter was shown in Figure 2. The estimated wholesale price for mixes of $20 \% \mathrm{BC}$ and $10 \% \mathrm{VC}$ by volume with the rest $(70 \%)$ being the CS (20BC:10VC:70CS), 20BC:15VC:65CS, 40BC:15VC:45CS, 20BC:20VC:60CS, 40BC:20VC:40CS, and 60BC:20VC:20CS was higher than the 100\% CS (control), while the other BC:VC:CS mixes were all cheaper than the control. The cheapest treatment (80BC:5VC:15CS) was only $61.6 \%$ of the price of the CS. The nutrient concentration (N, P, K, Ca, Mg, S, B, Ca, Cu, Fe, Mn, Na, and Zn) of the CS, $\mathrm{BC}$, and VC were tested by the Texas A\&M AgriLife Extension Service Soil, Water and Forage Testing Laboratory in College Station, TX, USA and shown in Table 1. 


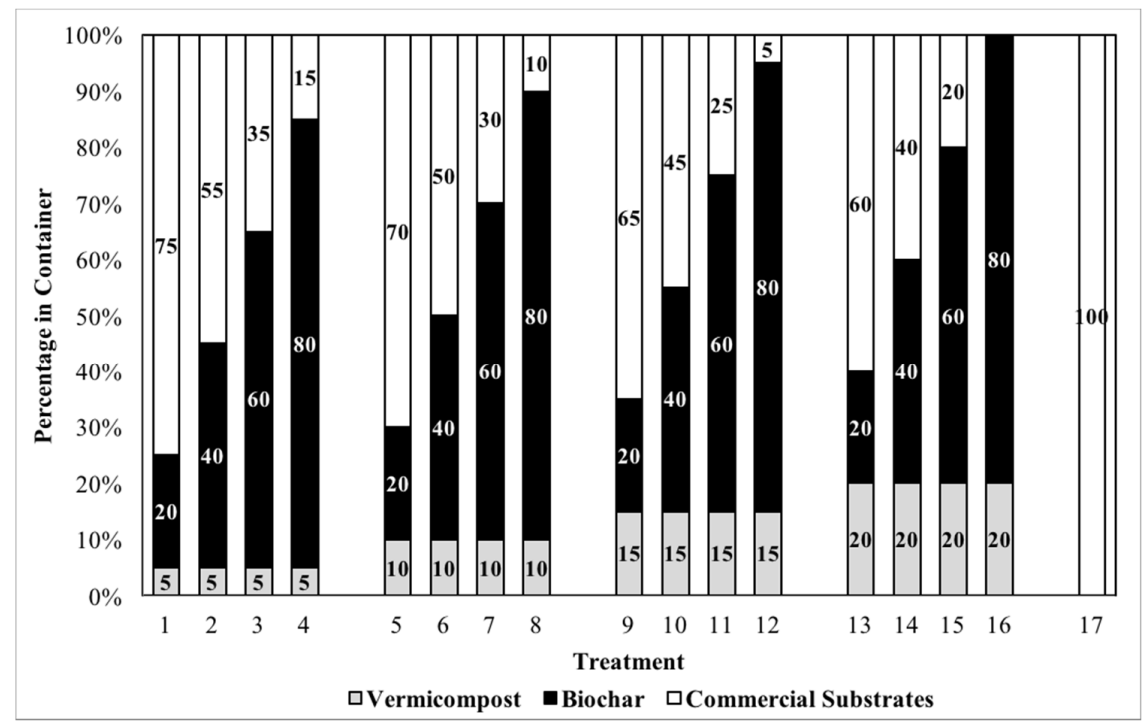

Figure 1. Seventeen formulated substrates including mixes of biochar $(20 \%, 40 \%, 60 \%$, or $80 \%$, by volume) with vermicompost $(5 \%, 10 \%, 15 \%$, or $20 \%$, by volume) and the $100 \%$ commercial peat-based substrates, Berger BM7 35BKS.

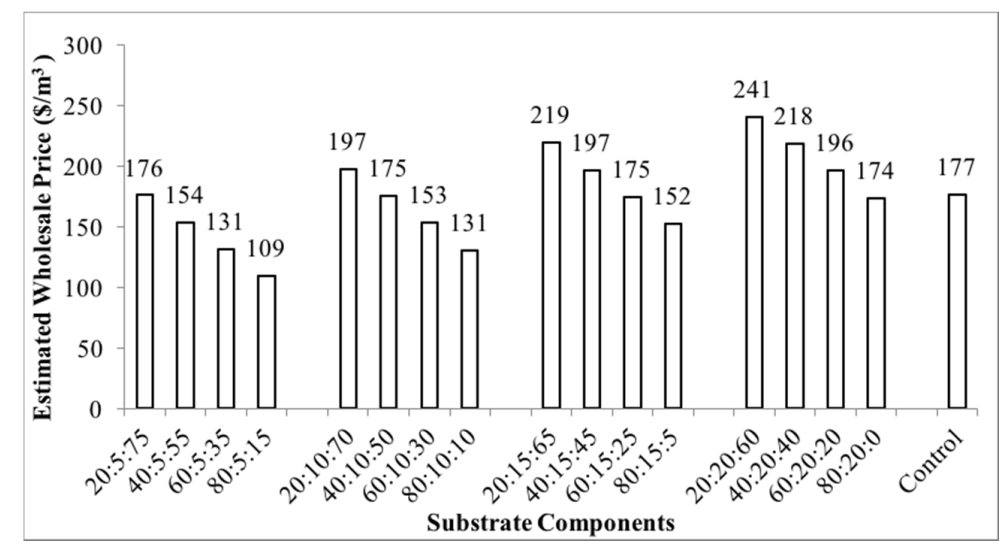

Figure 2. The estimated wholesale price (\$) for the 17 formulated substrates per cubic meter. The ratios on the $\mathrm{X}$-axis indicate the percentage ratio of biochar to vermicompost to commercial substrate (by volume). The control was $100 \%$ commercial substrate (Berger BM7 35BKS).

Table 1. Nutrient analysis of the commercial substrate (CS, Berger BM7 35BKS), biochar (BC), and vermicompost (VC).

\begin{tabular}{|c|c|c|c|c|c|c|c|c|c|c|c|c|}
\hline \multirow{2}{*}{ Substrate } & $\mathbf{N}$ & $\mathbf{P}$ & $\mathbf{K}$ & $\mathrm{Ca}$ & Mg & $S$ & $\mathrm{Fe}$ & B & $\mathrm{Cu}$ & Mn & $\mathrm{Na}$ & Zn \\
\hline & $(\%)$ & \multicolumn{11}{|c|}{$\left(\mathrm{mg} \mathrm{kg}^{-1}\right)$} \\
\hline CS & $0.70 b^{z}$ & $540 \mathrm{~b}$ & $1265 c$ & $25108 \mathrm{a}$ & $4237 \mathrm{a}$ & $1744 \mathrm{~b}$ & $1508 \mathrm{~b}$ & $11 \mathrm{~b}$ & $17 \mathrm{~b}$ & $98 \mathrm{c}$ & $953 \mathrm{a}$ & $46 \mathrm{~b}$ \\
\hline BC & $0.23 c$ & $456 \mathrm{~b}$ & $6362 \mathrm{a}$ & 27507 a & $1299 \mathrm{~b}$ & $231 \mathrm{~b}$ & $2039 \mathrm{~b}$ & 15 & $9 \mathrm{~b}$ & $905 \mathrm{a}$ & 107 & $13 \mathrm{~b}$ \\
\hline VC & $2.43 \mathrm{a}$ & $4901 \mathrm{a}$ & $3714 \mathrm{~b}$ & $25841 \mathrm{a}$ & $3819 a$ & 5996 a & $4835 \mathrm{a}$ & $42 \mathrm{a}$ & $165 \mathrm{a}$ & $374 \mathrm{~b}$ & $351 \mathrm{~b}$ & $385 \mathrm{a}$ \\
\hline
\end{tabular}

${ }^{\mathrm{z}}$ Means within a column under each mean factor followed by the same letter are not significantly different according to the Tukey's HSD test at $p<0.05(n=4)$.

The $\mathrm{pH}$ of the CS, BC, and VC was measured by using a handheld pH-EC meter (HI 98129, Hanna Instruments, Woonsocket, RI, USA), and the EC was measured by using the Bluelab Combo Meter (Bluelab Corporation Limited, Tauranga, New Zealand) according to the pour-through extraction method [56]. The $\mathrm{pH}$ of the CS was 6.06, and the EC was $1.3 \mathrm{dS} \mathrm{m}^{-1}$, respectively. The $\mathrm{pH}$ of the $\mathrm{BC}$ was 11.18 and the EC was $2.0 \mathrm{dS} \mathrm{m}^{-1}$, respectively. The $\mathrm{pH}$ of the VC was 4.8 and the EC was $6.7 \mathrm{dS} \mathrm{m}^{-1}$, respectively. The total porosity, container capacity, air space, and bulk density of the BC were $84.7 \%$, 
$60.3 \%, 24.4 \%$, and $0.15 \mathrm{~g} \mathrm{~cm}^{-3}$, respectively. Particle size distribution of the BC was determined by passing $40 \mathrm{~g} B C$ through 2.8, 2, 1, 0.425, and $0.25 \mathrm{~mm}$ sieves, and the weight was measured to determine the percentage of each particle size. Percentages of the $\mathrm{BC}$ particles ranging from greater than $2.8 \mathrm{~mm}$, $2.0 \mathrm{~mm}$ to $2.8 \mathrm{~mm}, 1.0 \mathrm{~mm}$ to $2.0 \mathrm{~mm}, 0.425 \mathrm{~mm}$ to $1.0 \mathrm{~mm}, 0.25 \mathrm{~mm}$ to $0.425 \mathrm{~mm}$, and smaller than $0.25 \mathrm{~mm}$ in diameter were $47.9 \%, 19.4 \%, 19.4 \%, 9.1 \%, 2.0 \%$, and $2.2 \%(w / w)$, respectively.

Six replications of the 17 treatments (16 BC:VC:CS mixes plus control) were arranged in randomized complete blocks in the greenhouse located on Texas A\&M University campus, College Station, TX, USA to control the environmental variance. The temperature, humidity, and dew point in the greenhouse were monitored using Watchdog (Spectrum Technologies Inc., Paxinos, PA, USA). During the experimental period, the average greenhouse temperature, relative humidity, and dew point were $20.5^{\circ} \mathrm{C}, 76.0 \%$, and $15.4{ }^{\circ} \mathrm{C}$, respectively. The basil plants were irrigated with $200 \mathrm{mg}$ nitrogen $(\mathrm{N}) \mathrm{L}^{-1}$ (20N-4.4 P-16.6K) Peters ${ }^{\circledR}$ Professional (Everris NA Inc., Dublin, OH, USA) nutrient solution. The tomato plants were irrigated with $200 \mathrm{mg} \mathrm{N} \mathrm{L}^{-1}$ (20N-4.4P-16.6K) Peters ${ }^{\circledR}$ Professional nutrient solution from 0 to 3 weeks after transplanting (WAT) and changed to $300 \mathrm{mg} \mathrm{N} \mathrm{L}^{-1}$ from 4 WAT. The total $\mathrm{N}$ in Peters ${ }^{\circledR}$ Professional contains $8.1 \%$ ammoniacal $\mathrm{N}$ and $11.9 \%$ nitrate $\mathrm{N}$. The $\mathrm{pH}$ of the $200 \mathrm{mg} \mathrm{N} \mathrm{L}^{-1}$ (20N-4.4P-16.6K) Peters ${ }^{\circledR}$ Professional nutrient solution was 6.1, and the EC was $1.0 \mathrm{dS} \mathrm{m}^{-1}$. The $\mathrm{pH}$ of the $300 \mathrm{mg} \mathrm{N} \mathrm{L}^{-1}$ (20N-4.4P-16.6K) Peters ${ }^{\circledR}$ Professional nutrient solution was 5.9 , and the EC was $1.3 \mathrm{dS} \mathrm{m}^{-1}$.

\subsection{Substrate Physical Properties and Substrate Leachate $p H$}

Four replications of each substrate were tested to determine physical properties including the bulk density, total porosity, air space, and container capacity of the 17 substrates using the porometers of the North Carolina State University Horticultural Substrates Laboratory [57]. The substrate leachate $\mathrm{pH}$ was measured at 0, 2, 4, 6, and 9 WAT using a handheld pH-EC meter (HI 98129, Hanna Instrument, Woonsocket, RI, USA) according to the pour-through extraction method using the same amount of leachate for each test [56].

\subsection{Plant Growth and Development}

The plant growth index (GI) of each plant was measured at 0, 2, 4, 6, and 9 WAT, respectively. The height of the plant was measured from the medium surface to the highest point of the plant. The widest plant canopy width and its perpendicular width were measured. The plant GI was determined by the following formula: GI = plant height $/ 2+$ (plant width $1+$ plant width 2$) / 4$ [58]. The leaf chlorophyll content of each plant was measured as soil plant analysis development (SPAD) values at 2, 4, 6, and 9 WAT, respectively using a portable SPAD 502 Plus Chlorophyll Meter (Spectrum Technologies, Inc., Plainfield, IL, USA). Plant leaves were too small to measure SPAD at 0 WAT. The leaf greenness of each plant was determined using the average of readings from three mature leaves.

At the end of nine WAT, plants were harvested to measure DW. For each tomato plant, the stems, leaves, root, and combined fruits and flowers were harvested separately. For each basil plant, the shoot and root were harvested separately. All the plant parts were oven-dried at $80^{\circ} \mathrm{C}$ to constant weight before the DW measurements. The total DW of each plant was calculated by adding the DW of all parts of the plant.

\subsection{Statistical Analysis}

Data were analyzed with one-way analysis of variance (ANOVA) using JMP Statistical Software (version Pro 12.2.0; SAS Institute, Cary, NC, USA) to test the effect of different substrates on the physical and chemical properties and plant growth. The type of substrate was the main factor. Tukey's Honestly Significant Difference (HSD) tests were used for the comparison of means among treatments at $p<0.05$. Tomato and basil plants were treated as independent studies and were not compared. 


\section{Results and Discussion}

\subsection{Physical Properties of the Container Substrates}

The total porosity of all the BC:VC:CS mixes was similar to the control (Figure 3a). There was no difference between the container capacity of the mixes of BC $(20 \%$ or $40 \%)$ with $\mathrm{VC}(5 \%, 10 \%$, or $15 \%)$ and the control (Figure 3b). The container capacity of $80 \%$ BC mixes were significantly lower than the control, since BC had lower container capacity $(60.3 \%)$ than that of CS (70.7\%). The air space of 80BC:5VC:15CS, 60BC:20VC:20CS, and 80BC:20VC:0CS was higher than that of the control due to the high incorporation rate of $\mathrm{BC}$ with large particle size (Figure 3c), which increased the macropores and thus the air space. The fraction of BC with size greater than $2.8 \mathrm{~mm}(47.9 \%)$ was higher than that of CS $(25.4 \%)$ and VC (1.2\%). The past research showed the variable results of the substrates' physical properties after BC incorporation. Tian et al. [10] reported that the total porosity and container capacity of peat substrate with or without $50 \%$ (by volume) green waste BC were similar, while others found that the total porosity and container capacity of the substrates increased with the increasing BC rate [59-61]. Guo et al. [62] found that the air space increased as the pine wood BC rate increased. Yu et al. [63] indicated that the air space increased with the increasing mixed hardwood $\mathrm{BC}$ incorporation rate from $10 \%$ to $100 \%$ (by volume), but the trend was totally opposite for sugarcane bagasse BC. Another research showed that the substitution of peat with $10 \%$ (by volume) sewage sludge BC caused no difference on the air space in comparison with the $100 \%$ peat substrate control [64]. The effect of BC incorporation on a substrate's physical properties is BC-specific. Container substrates hold water in the micropores between or inside the container substrate components' particles [65]. The container capacity would be increased if the incorporation of BC leads to a higher fraction of micropores. Air space is the proportion of air-filled macropores after the water drains [65]. Air space is closely related to the particle size distributions of $\mathrm{BC}$ and the other substrate components, and the changed interporosity after BC incorporation affects air space. The effect of BC on total porosity is related to container capacity and air space, since total porosity is the sum of container capacity and air space.

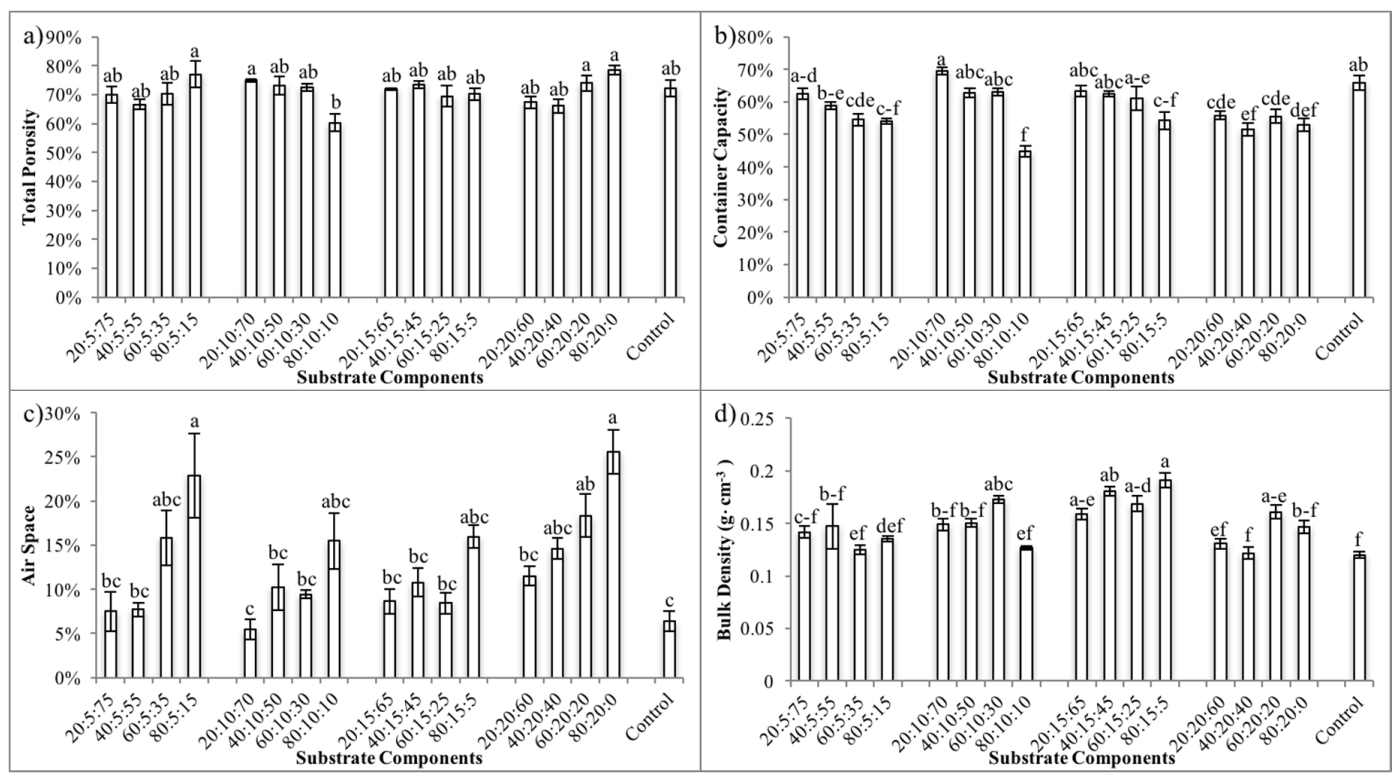

Figure 3. Total porosity (a), container capacity (b), air space (c), and bulk density (d) (mean \pm standard error) of the 17 different formulated substrates. The ratios on the $X$-axis indicate the percentage ratio of biochar to vermicompost to commercial substrate (by volume). The control was $100 \%$ commercial substrate (Berger BM7 35BKS). Means indicated by the same letter are not significantly different according to Tukey's Honestly Significant Difference (HSD) test at $p<0.05(n=4)$. 
The bulk density of 15\% VC mixes, 60BC:10VC:30CS, and 60BC:20VC:20CS was higher than that of the control (Figure 3d). The increased bulk density could be due to the high bulk density of VC $\left(0.38 \mathrm{~g} \mathrm{~cm}^{-3}\right)$ and $\mathrm{BC}\left(0.15 \mathrm{~g} \mathrm{~cm}^{-3}\right)$ compared to the control $\left(0.10 \mathrm{~g} \mathrm{~cm}^{-3}\right)$. Similar to our results, a lot of research has shown that substitution of the commonly used substrate with BC could increase bulk density $[13,23,29]$.

\subsection{Substrate Leachate $\mathrm{pH}$}

Compared to the control, the substrate leachate $\mathrm{pH}$ in all $\mathrm{BC}: \mathrm{VC}: \mathrm{CS}$ mixes was increased, except for those of the 20BC:5VC:75CS and 20BC:10VC:70CS mixes with tomato plants at 9 WAT (see Table S1). The increased $\mathrm{pH}$ was probably due to the high $\mathrm{pH}$ of the $\mathrm{BC}$ (11.18) used in this experiment. The liming effect of $\mathrm{BC}$ was found in a lot of research [66-68]. In addition, substrate leachate $\mathrm{pH}$ tended to slightly decrease during the study (see Table S1), which was possibly due to the acidifying effect of the fertilizer $20 \mathrm{~N}-4.4 \mathrm{P}-16.6 \mathrm{~K}$ Peters ${ }^{\circledR}$ Professional (a potential acidity of $188 \mathrm{~kg}$ calcium carbonate equivalent per $1000 \mathrm{~kg}$ of the fertilizer). Therefore, the reason for the similar $\mathrm{pH}$ of mixes of 20BC:5VC:75CS and 20BC:10VC:70CS with tomato plants at 9 WAT with the control could be due to the low percentage of the $\mathrm{BC}$ incorporation rate and the relative large amount of nutrient solution applied to the tomato plants for 9 weeks 'washing down' the substrate leachate $\mathrm{pH}$.

\subsection{Plant Growth and Development}

For basil, BC:VC:CS mixes caused no negative effect on the SPAD readings in comparison with the control at 2, 4, 6, or 9 WAT (see Table S2). For tomato, the SPAD readings of the plants in BC:VC:CS mixes were similar to or higher than those in the control at 2, 4, and 6 WAT, while at 9 WAT, the leaf SPAD readings of tomato plants grown in the 80BC:5VC:15CS, 80BC:15VC:5CS, and 80BC:20VC:0CS mixes were lower than those in the control (see Table S2). Similarly, Liu et al. [47] found that SPAD readings of bell pepper leaves in mixes of $\mathrm{BC}(70 \%, 80 \%$, and $90 \%$, by volume) with the rest being VC were lower than those in commercial substrates. The decreased leaf SPAD readings at 9 WAT could be caused by two reasons. First, it was shown that leaf SPAD readings was closely related to leaf N concentration, and lower SPAD readings indicated lower leaf $\mathrm{N}$ concentration [69]. The decreased SPAD readings could be due to the $B C^{\prime}$ s ability to immobilize $N$ [70]. Second, the increased substrate $\mathrm{pH}$ after the incorporation of the $\mathrm{BC}$ with high $\mathrm{pH}$ (11.18) could reduce iron (Fe) availability, causing decreased leaf greenness. It was shown that shoot Fe concentration was lower at substrate with higher $\mathrm{pH}$ [71], and leaf SPAD readings were significantly correlated with Fe availability, since Fe is essential for the chlorophyll synthesis [72]. The leaf chlorosis (as measured by chlorophyll concentration) could be more severe with less iron concentration [73]. The reason for the decreased leaf SPAD readings of the tomato plants only shown at 9 WAT was due to the nutrient deficiency of the leaves caused by the strong nutrient sink (fruits and flowers) at that stage, since all the tomato plants had flowers and fruits at 9 WAT.

However, the possible $\mathrm{N}$ binding of $\mathrm{BC}$ and reduced $\mathrm{Fe}$ availability caused by increased $\mathrm{pH}$ did not decrease the plant GI and DW of either tomato or basil plants in this research. The GIs of both basil and tomato plants grown in BC:VC:CS mixes were similar to those in the control at 9 WAT (see Figure S1). All basil plants grown in BC:VC:CS mixes had similar shoot and total DWs in comparison with the control (see Figure S2). The root DWs of basil plants in BC:VC:CS mixes were similar to or higher than those in 100\% CS, with those in 60BC:15VC:25CS being the highest among all treatments (Figure 4). Similarly, all tomato plants grown in BC:VC:CS mixes had similar DWs (the combined flower and fruit, leaf, stem, root, and total DW) with respect to the control (see Figure S3). The reasons for the enhanced plant growth could be the VC's extra nutrient supply and the $\mathrm{BC}^{\prime}$ 's nutrient-holding ability. Similar results were reported by Huang et al. [74], who indicated that tomato and basil plant growth in mixes of $\mathrm{BC}(60 \%$ or $70 \%$, by volume) with either $5 \%$ VC or chicken manure compost with the rest being CS was similar to or higher than the control. Alvarez et al. [44] also found that the amendment of VC 
$(10 \%, 20 \%, 30 \%, 40 \%$, and $50 \%$, by volume) and $\mathrm{BC}(4 \%, 8 \%$, and $12 \%$, by volume) to a peat-based substrate did not adversely affect the petunia shoot DW.

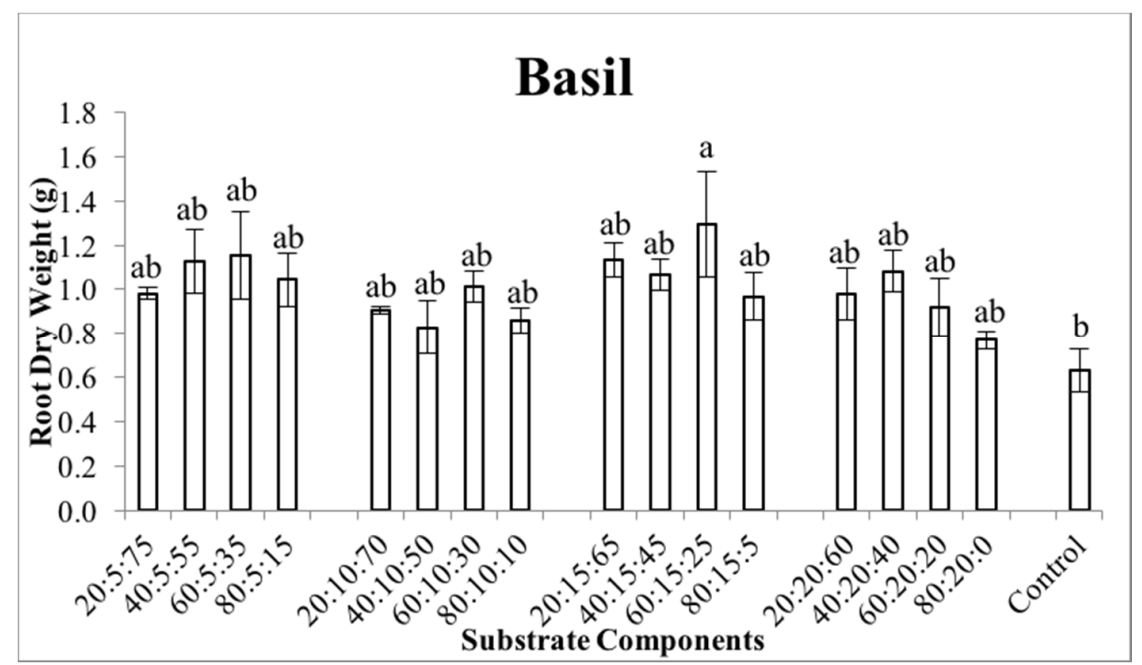

Figure 4. Root dry weight (mean \pm standard error) per basil plant harvested at 9 weeks after transplanting. The ratios on the $X$-axis indicate the percentage ratio of biochar to vermicompost to commercial substrate (by volume). The control was 100\% commercial substrate (Berger BM7 35BKS). Means indicated by the same letter are not significantly different according to Tukey's HSD test at $p<0.05(n=6)$.

\section{Conclusions}

The mixes of mixed hardwood BC $(20 \%, 40 \%, 60 \%$, or $80 \%$, by volume) made from fast pyrolysis and VC $(5 \%, 10 \%, 15 \%$, or $20 \%$, by volume) used in this study had the potential to replace the CS to grow basil and tomato plants. Our results found difference in the substrate leachate $\mathrm{pH}$ between the $100 \%$ CS and BC:VC:CS mixes except for 20BC:5VC:75CS and 20BC:10VC:70CS with tomato plants at 9 WAT, which indicated the liming effect of the mixed hardwood $\mathrm{BC}$ used in this research. At 9 WAT, the leaf SPAD readings of tomato plants grown in 80BC:5VC:15CS, 80BC:15VC:5CS, and 80BC:20VC:0CS mixes were lower than those in the control, which was possibly due to the binding ability of $\mathrm{BC}$ or reduced Fe availability caused by increased substrate $\mathrm{pH}$ after $\mathrm{BC}$ incorporation. The growth index and total dry weight of basil and tomato plants in BC:VC:CS mixes were similar to those in the CS. Considering the cost of the alternative substrates, all the BC:VC:CS mixes (except for 20BC:10VC:70CS, 20BC:15VC:65CS, 40BC:15VC:45CS, 20BC:20VC:60CS, 40BC:20VC:40CS, and 60BC:20VC:20CS) in this experiment could be selected as the suitable ones to grow plants, with the 80BC:5VC:15CS being the cheapest and most recommended. This study is important for the future use of mixtures of BC with VC in container substrate for greenhouse and nursery plant production to provide a sustainable and environmentally friendly way to substitute peat use in agriculture and add value to the bioenergy process by using the by-product BC. Using the BC:VC:CS mixes with wholesale prices cheaper than the $100 \%$ CS could provide more economical ways to grow plants and benefit the growers. Tomato and basil plants were used as model plants in this study. Since results were similar for these two plants with different optimal growing conditions, these results could be applicable to many other plants. The results in this study can be only suitable for the specific mixed hardwood $\mathrm{BC}$ made from pyrolysis and VC (Pachamama earthworm castings; Lady Bug Brand) due to the complexity of BC and VC. More mixed hardwood $\mathrm{BC}$ incorporation percentages and other potential amendment candidates need to be tested for economic viability. 
Supplementary Materials: The following are available online at http://www.mdpi.com/2073-4395/10/2/224/s1, Table S1: The leachate $\mathrm{pH}$ of the 17 substrates with basil and tomato plants at 0, 2, 4, 6, and 9 weeks after transplanting (WAT), Table S2: The SPAD reading of basil and tomato leaves in 17 substrates at 2, 4, 6, and 9 weeks after transplanting (WAT), Figure S1: Cumulative growth index (mean \pm standard error) per basil (a) or tomato (b) plant grown in 17 substrates at 0, 2, 4, 6, and 9 weeks after transplanting (WAT), Figure S2: Shoot (a) and total (b) dry weight (mean \pm standard error) per basil plant harvested at 9 weeks after transplanting, and Figure S3: Leaves (a), stem (b), root (c), combined flower and fruit (d), and total (e) dry weight (mean \pm standard error) per tomato plant harvested at 9 weeks after transplanting.

Author Contributions: Conceptualization, L.H., M.G., and X.L.; Data curation, L.H.; Formal analysis, L.H.; Investigation, L.H., P.Y., C.Z., and X.L.; Resources, M.G.; Supervision, M.G. and X.L.; Writing—original draft, L.H.; Writing-review and editing, M.G., P.Y., C.Z., and X.L. All authors have read and agreed to the published version of the manuscript.

Funding: This research received no external funding.

Acknowledgments: The authors thank the Agriculture Women Excited to Share Opinions, Mentoring, and Experiences (AWESOME) faculty group of the College of Agriculture and Life Sciences at Texas A\&M University for assistance with editing the manuscript.

Conflicts of Interest: The authors declare no conflict of interest.

\section{References}

1. Webber, C.L., III; White, P.M., Jr.; Gu, M.; Spaunhorst, D.J.; Lima, I.M.; Petrie, E.C. Sugarcane and pine biochar as amendments for greenhouse growing media for the production of bean (Phaseolus vulgaris L.) seedlings. J. Agric. Sci. 2018, 10, 58-68. [CrossRef]

2. Choi, H.-S.; Zhao, Y.; Dou, H.; Cai, X.; Gu, M.; Yu, F. Effects of biochar mixtures with pine-bark based substrates on growth and development of horticultural crops. Horti. Environ. Biotechnol. 2018, 59, 345-354. [CrossRef]

3. Peng, D.; Gu, M.; Zhao, Y.; Yu, F.; Choi, H.-S. Effects of biochar mixes with peat-moss based substrates on growth and development of horticultural crops. Hortic. Sci. Technol. 2018, 36, 501-512.

4. Gvero, P.M.; Papuga, S.; Mujanic, I.; Vaskovic, S. Pyrolysis as a key process in biomass combustion and thermochemical conversion. Therm. Sci. 2016, 20, 154. [CrossRef]

5. Rahman, A.A.; Sulaiman, F.; Abdullah, N. Influence of washing medium pre-treatment on pyrolysis yields and product characteristics of palm kernel shell. J. Phys. Sci. 2016, 27, 53.

6. Hansen, V.; Müller-Stöver, D.; Ahrenfeldt, J.; Holm, J.K.; Henriksen, U.B.; Hauggaard-Nielsen, H. Gasification biochar as a valuable by-product for carbon sequestration and soil amendment. Biomass Bioenergy 2015, 72, 300-308. [CrossRef]

7. Altland, J.E.; Locke, J.C. Gasified rice hull biochar is a source of phosphorus and potassium for container-grown plants. J. Environ. Hortic. 2013, 31, 138-144.

8. Laird, D.A. The charcoal vision: A win-win-win scenario for simultaneously producing bioenergy, permanently sequestering carbon, while improving soil and water quality. Agron. J. 2008, 100, 178-181.

9. Zheng, W.; Sharma, B.; Rajagopalan, N. Using Biochar as a Soil Amendment for Sustainable Agriculture; Illinois Sustainable Technology Center: Champaign, IL, USA, 2010.

10. Tian, Y.; Sun, X.; Li, S.; Wang, H.; Wang, L.; Cao, J.; Zhang, L. Biochar made from green waste as peat substitute in growth media for Calathea rotundifola cv. Fasciata. Sci. Hortic. 2012, 143, 15-18. [CrossRef]

11. Buss, W.; Graham, M.C.; Shepherd, J.G.; Mašek, O. Risks and benefits of marginal biomass-derived biochars for plant growth. Sci. Total Environ. 2016, 569, 496-506. [CrossRef]

12. Xu, G.; Zhang, Y.; Sun, J.; Shao, H. Negative interactive effects between biochar and phosphorus fertilization on phosphorus availability and plant yield in saline sodic soil. Sci. Total Environ. 2016, 568, 910-915. [CrossRef] [PubMed]

13. Vaughn, S.F.; Kenar, J.A.; Thompson, A.R.; Peterson, S.C. Comparison of biochars derived from wood pellets and pelletized wheat straw as replacements for peat in potting substrates. Ind. Crops Prod. 2013, 51, 437-443. [CrossRef]

14. Hansen, V.; Hauggaard-Nielsen, H.; Petersen, C.T.; Mikkelsen, T.N.; Müller-Stöver, D. Effects of gasification biochar on plant-available water capacity and plant growth in two contrasting soil types. Soil Till. Res. 2016, 161, 1-9. [CrossRef] 
15. Locke, J.C.; Altland, J.E.; Ford, C.W. Gasified rice hull biochar affects nutrition and growth of horticultural crops in container substrates. J. Environ. Hortic. 2013, 31, 195-202.

16. Yu, F.; Steele, P.H.; Gu, M.; Zhao, Y. Using Biochar as Container Substrate for Plant Growth. U.S. Patent 9,359,267 B2, 7 June 2016.

17. Huang, L.; Gu, M. Effects of biochar on container substrate properties and growth of plants-A review. Horticulturae 2019, 5, 14. [CrossRef]

18. Chrysargyris, A.; Prasad, M.; Kavanagh, A.; Tzortzakis, N. Biochar type and ratio as a peat additive/partial peat replacement in growing media for cabbage seedling production. Agronomy 2019, 9, 693. [CrossRef]

19. Prasad, M.; Chrysargyris, A.; McDaniel, N.; Kavanagh, A.; Gruda, N.S.; Tzortzakis, N. Plant nutrient availability and $\mathrm{pH}$ of biochars and their fractions, with the possible use as a component in a growing media. Agronomy 2020, 10, 10. [CrossRef]

20. Gruda, N.S. Increasing sustainability of growing media constituents and stand-alone substrates in soilless culture systems. Agronomy 2019, 9, 298. [CrossRef]

21. Hatala, J.A.; Detto, M.; Sonnentag, O.; Deverel, S.J.; Verfaillie, J.; Baldocchi, D.D. Greenhouse gas $\left(\mathrm{CO}_{2}\right.$, $\mathrm{CH}_{4}, \mathrm{H}_{2} \mathrm{O}$ ) fluxes from drained and flooded agricultural peatlands in the Sacramento-San Joaquin Delta. Agric. Ecosyst. Environ. 2012, 150, 1-18. [CrossRef]

22. Leifeld, J.; Menichetti, L. The underappreciated potential of peatlands in global climate change mitigation strategies. Nat. Commun. 2018, 9, 1071. [CrossRef]

23. Dumroese, R.K.; Heiskanen, J.; Englund, K.; Tervahauta, A. Pelleted biochar: Chemical and physical properties show potential use as a substrate in container nurseries. Biomass Bioenergy 2011, 35, 2018-2027. [CrossRef]

24. Crutchfield, E.F.; McGiffen, M.E., Jr.; Merhaut, D.J. Effects of biochar on nutrient leaching and begonia plant growth. J. Environ. Hortic. 2018, 36, 126-132.

25. Zulfiqar, F.; Younis, A.; Chen, J. Biochar or biochar-compost amendment to a peat-based substrate improves growth of Syngonium podophyllum. Agronomy 2019, 9, 460. [CrossRef]

26. Dispenza, V.; De Pasquale, C.; Fascella, G.; Mammano, M.M.; Alonzo, G. Use of biochar as peat substitute for growing substrates of Euphorbia $\times$ lomi potted plants. Span. J. Agric. Res. 2016, 14, e0908. [CrossRef]

27. Nieto, A.; Gascó, G.; Paz-Ferreiro, J.; Fernández, J.; Plaza, C.; Méndez, A. The effect of pruning waste and biochar addition on brown peat based growing media properties. Sci. Hortic. 2016, 199, 142-148. [CrossRef]

28. Kadota, M.; Niimi, Y. Effects of charcoal with pyroligneous acid and barnyard manure on bedding plants. Sci. Hortic. 2004, 101, 327-332. [CrossRef]

29. Vaughn, S.F.; Eller, F.J.; Evangelista, R.L.; Moser, B.R.; Lee, E.; Wagner, R.E.; Peterson, S.C. Evaluation of biochar-anaerobic potato digestate mixtures as renewable components of horticultural potting media. Ind. Crops Prod. 2015, 65, 467-471. [CrossRef]

30. Yu, P.; Huang, L.; Li, Q.; Lima, I.M.; White, P.M.; Gu, M. Effects of mixed hardwood and sugarcane biochar as bark-based substrate substitutes on container plants production and nutrient leaching. Agronomy 2020, 10, 156. [CrossRef]

31. Gu, M.; Li, Q.; Steele, P.H.; Niu, G.; Yu, F. Growth of 'fireworks' gomphrena grown in substrates amended with biochar. J. Food Agric. Environ. 2013, 11, 819-821.

32. Housley, C.; Kachenko, A.; Singh, B. Effects of eucalyptus saligna biochar-amended media on the growth of Acmena smithii, Viola var. hybrida, and Viola $\times$ wittrockiana. J. Hortic. Sci. Biotechnol. 2015, 90, 187-194. [CrossRef]

33. Webber, C.L., III; White, P.M., Jr.; Spaunhorst, D.J.; Lima, I.M.; Petrie, E.C. Sugarcane biochar as an amendment for greenhouse growing media for the production of cucurbit seedlings. J. Agric. Sci. 2018, 10, 104. [CrossRef]

34. Mitchell, M.; Hornor, S.; Abrams, B. Decomposition of sewage sludge in drying beds and the potential role of the earthworm, Eisenia foetida. J. Environ. Qual. 1980, 9, 373-378. [CrossRef]

35. Edwards, C. Production of feed protein from animal waste by earthworms. Philos. Trans. R. Soc. Lond. B Biol. Sci. 1985, 310, 299-307.

36. Chan, P.L.; Griffiths, D. The vermicomposting of pre-treated pig manure. Biol. Wastes 1988, 24, 57-69. [CrossRef]

37. Hartenstein, R.; Bisesi, M.S. Use of earthworm biotechnology for the management of effluents from intensively housed livestock. Outlook Agric. 1989, 18, 72-76. [CrossRef] 
38. Manna, M.; Jha, S.; Ghosh, P.; Ganguly, T.; Singh, K.; Takkar, P. Capacity of various food materials to support growth and reproduction of epigeic earthworms on vermicompost. J. Sustain. For. 2005, 20, 1-15. [CrossRef]

39. Sinha, R.K.; Agarwal, S.; Chauhan, K.; Valani, D. The wonders of earthworms \& its vermicompost in farm production: Charles darwin's 'friends of farmers', with potential to replace destructive chemical fertilizers. Agric. Sci. 2010, 1, 76.

40. Atiyeh, R.; Subler, S.; Edwards, C.; Bachman, G.; Metzger, J.; Shuster, W. Effects of vermicomposts and composts on plant growth in horticultural container media and soil. Pedobiologia 2000, 44, 579-590. [CrossRef]

41. Edwards, C.A.; Burrows, I. Potential of earthworm composts as plant growth media. In Earthworms in Waste and Environmental Management; Edwards, C.A., Neuhauser, E.F., Eds.; SPB Academic Publishing: The Hague, The Netherlands, 1988.

42. McGinnis, M.; Bilderback, T.; Warren, S. Vermicompost amended pine bark provides most plant nutrients for Hibiscus moscheutos 'Luna Blush'. Acta Hortic. 2011, 891, 249-256. [CrossRef]

43. Abbey, L.; Young, C.; Teitel-Payne, R.; Howe, K. Evaluation of proportions of vermicompost and coir in a medium for container-grown Swiss chard. Int. J. Veg. Sci. 2012, 18, 109-120. [CrossRef]

44. Alvarez, J.; Pasian, C.; Lal, R.; López, R.; Fernández, M. Vermicompost and biochar as substitutes of growing media in ornamental-plant production. J. Appl. Hortic. 2017, 19, 205-214.

45. Álvarez, J.M.; Pasian, C.; Lal, R.; López, R.; Díaz, M.J.; Fernández, M. Morpho-physiological plant quality when biochar and vermicompost are used as growing media replacement in urban horticulture. Urban For. Urban Green. 2018, 34, 175-180. [CrossRef]

46. Szczech, M.; Smolińska, U. Comparison of suppressiveness of vermicomposts produced from animal manures and sewage sludge against Phytophthora nicotianae Breda de Haan var. nicotianae. J. Phytopathol. 2001, 149, 77-82. [CrossRef]

47. Liu, R.; Gu, M.; Huang, L.; Yu, F.; Jung, S.-K.; Choi, H.-S. Effect of pine wood biochar mixed with two types of compost on growth of bell pepper (Capsicum annuum L.). Hortic. Environ. Biotechnol. 2019, 60, 313-319. [CrossRef]

48. Abushita, A.A.; Hebshi, E.A.; Daood, H.G.; Biacs, P.A. Determination of antioxidant vitamins in tomatoes. Food Chem. 1997, 60, 207-212. [CrossRef]

49. Jones, J.B., Jr. Tomato plant culture. In The Field, Greenhouse, and Home Garden; CRC Press: Boca Raton, FL, USA, 2007.

50. Makri, O.; Kintzios, S. Ocimum sp. (basil): Botany, cultivation, pharmaceutical properties, and biotechnology. J. Herbs Spices Med. Plants 2008, 13, 123-150. [CrossRef]

51. Bernstein, N.; Sela, S.; Dudai, N.; Gorbatsevich, E. Salinity stress does not affect root uptake, dissemination and persistence of salmonella in sweet-basil (Ocimum basilicum). Front. Plant Sci. 2017, 8, 675. [CrossRef]

52. Grayer, R.J.; Kite, G.C.; Goldstone, F.J.; Bryan, S.E.; Paton, A.; Putievsky, E. Infraspecific taxonomy and essential oil chemotypes in sweet basil, Ocimum basilicum. Phytochemistry 1996, 43, 1033-1039. [CrossRef]

53. Sharafzadeh, S.; Alizadeh, O. Nutrient supply and fertilization of basil. Adv. Environ. Biol. 2011, 5, 956-960.

54. Tesi, R.; Chisci, G.; Nencini, A.; Tallarico, R. Growth response to fertilisation of sweet basil (Ocimum basilicum L.). Acta Hortic. 1995, 390, 93-96. [CrossRef]

55. BWI Companies, Inc. Available online: https://www.bwicompanies.com/ (accessed on 2 February 2020).

56. LeBude, A.; Bilderback, T. The Pour-Through Extraction Procedure: A Nutrient Management Tool for Nursery Crops; AG-717-W:2009; North Carolina Cooperative Extension: Raleigh, NC, USA, 2009.

57. Fonteno, W.; Hardin, C.; Brewster, J. Procedures for Determining Physical Properties of Horticultural Substrates Using the NCSU Porometer; Horticultural Substrates Laboratory, North Carolina State University: Raleigh, NC, USA, 1995.

58. Guo, Y.; Niu, G.; Starman, T.; Volder, A.; Gu, M. Poinsettia growth and development response to container root substrate with biochar. Horticulturae 2018, 4, 1. [CrossRef]

59. Zhang, L.; Sun, X.-Y.; Tian, Y.; Gong, X.-Q. Biochar and humic acid amendments improve the quality of composted green waste as a growth medium for the ornamental plant Calathea insignis. Sci. Hortic. 2014, 176, 70-78. [CrossRef]

60. Fan, R.; Luo, J.; Yan, S.; Zhou, Y.; Zhang, Z. Effects of biochar and super absorbent polymer on substrate properties and water spinach growth. Pedosphere 2015, 25, 737-748. [CrossRef]

61. Méndez, A.; Paz-Ferreiro, J.; Gil, E.; Gascó, G. The effect of paper sludge and biochar addition on brown peat and coir based growing media properties. Sci. Hortic. 2015, 193, 225-230. [CrossRef] 
62. Guo, Y.; Niu, G.; Starman, T.; Gu, M. Growth and development of Easter lily in response to container substrate with biochar. J. Hortic. Sci. Biotechnol. 2018, 94, 80-86. [CrossRef]

63. Yu, P.; Li, Q.; Huang, L.; Niu, G.; Gu, M. Mixed hardwood and sugarcane bagasse biochar as potting mix components for container tomato and basil seedling production. Appl. Sci. 2019, 9, 4713. [CrossRef]

64. Méndez, A.; Cárdenas-Aguiar, E.; Paz-Ferreiro, J.; Plaza, C.; Gascó, G. The effect of sewage sludge biochar on peat-based growing media. Biol. Agric. Hortic. 2017, 33, 40-51. [CrossRef]

65. Landis, T.D. Growing media. Contain. Grow. Med. 1990, 2, 41-85.

66. Ducey, T.F.; Novak, J.M.; Johnson, M.G. Effects of biochar blends on microbial community composition in two coastal plain soils. Agriculture 2015, 5, 1060-1075. [CrossRef]

67. Streubel, J.; Collins, H.; Garcia-Perez, M.; Tarara, J.; Granatstein, D.; Kruger, C. Influence of contrasting biochar types on five soils at increasing rates of application. Soil Sci. Soc. Am. J. 2011, 75, 1402-1413. [CrossRef]

68. Chan, K.; Van Zwieten, L.; Meszaros, I.; Downie, A.; Joseph, S. Agronomic values of greenwaste biochar as a soil amendment. Soil Res. 2008, 45, 629-634. [CrossRef]

69. Li, Y.; Alva, A.; Calvert, D.; Zhang, M. A rapid nondestructive technique to predict leaf nitrogen status of grapefruit tree with various nitrogen fertilization practices. HortTechnology 1998, 8, 81-86. [CrossRef]

70. Nair, A.; Carpenter, B. Biochar rate and transplant tray cell number have implications on pepper growth during transplant production. HortTechnology 2016, 26, 713-719. [CrossRef]

71. Dickson, R.W.; Fisher, P.R.; Padhye, S.R.; Argo, W.R. Evaluating calibrachoa (Calibrachoa $\times$ hybrida cerv.) genotype sensitivity to iron deficiency at high substrate ph. HortScience 2016, 51, 1452-1457. [CrossRef]

72. Radhamani, R.; Kannan, R.; Rakkiyappan, P. Leaf chlorophyll meter readings as an indicator for sugarcane yield under iron deficient typic haplustert. Sugar Tech. 2016, 18, 61-66. [CrossRef]

73. Wallihan, E.F. Relation of chlorosis to concentration of iron in citrus leaves. Am. J. Bot. 1955, 42, 101-104. [CrossRef]

74. Huang, L.; Niu, G.; Feagley, S.E.; Gu, M. Evaluation of a hardwood biochar and two composts mixes as replacements for a peat-based commercial substrate. Ind. Crops Prod. 2019, 129, 549-560. [CrossRef]

(C) 2020 by the authors. Licensee MDPI, Basel, Switzerland. This article is an open access article distributed under the terms and conditions of the Creative Commons Attribution (CC BY) license (http://creativecommons.org/licenses/by/4.0/). 